\title{
An Exploration of The Multiple Role of Library in The Educational Activities at University Level
}

\author{
Dr. Maksal Minaz \\ Lecturer in Department of Education, Abdul Wali Khan University Mardan. \\ Email: maksalminaz@awkum.edu.pk.com \\ Dr. Rehmat Shah \\ Assistant professor of Education, Virtual University Lahore Pakistan. \\ Email: rehmatshah786@gmail.com \\ Mrs. Mehwish Habib \\ Demonstrator, Department of Education, Abdul Wali Khan University Mardan.
}

Received on: 11-10-2021

Accepted on: 13-11-2021

\begin{abstract}
The present specialized libraries are relied upon multi-disciplinary, multi-mode; multi-media as the specialized instruction requests it to assume the supporting part. This study focused on the objective to explore the multiple roles of library in students' educational activities at university level. Therefore, a survey was conducted at the social science block of Abdul Wali Khan University Mardan. Total Numbers of one hundred participants from social science discipline were randomly selected and data were collected through a self-made questionnaire. The questionnaire was pilot tested and gathers the data. Furthermore, data were analyzed by using percentage, mean scores and standard deviation were accordingly. Collected data showed that university students frequently visited library to boost-up their learning capabilities. The results of the collected data showed that library is a free source to educational activities and students easily access towards relevant material available at their approach. The major recommendation of study intensive on Higher Education Commission of Pakistan should take serious steps towards catalogue training for university teachers and students.
\end{abstract}

Keywords: Library, multi-disciplinary, multi-mode, multimedia, frequently, boost-up etc.

\section{INTRODUCTION}

According to Onohwakpor (2005) a single book shelf that is more expensive from gold and platinum, but the place which is full of thousands books and hundreds of shelfs is worth like a paradise of knowledge. A well-stocked library is the requirement of every educational institution which is the most common need in the educational activities.

According to the views of Akinpelu (1994) books are safely reserved and set in a proper way for the convenient of book lovers to select his choice according to his requirement. Before the 
Vol. II, Issue 3, Oct - December 2021

ISSN No: (ONLINE): 2710-043

www.irjei.com
International Research Journal of Education and Innovation

ISSN No: ISSN (PRINT): 2710-0448

DOI: https://doi.org/10.53575/irjei.v2.03(21)5.53-66

An Exploration of The Multiple Role of Library in The Educational Activities ...

selection and issuance of required book the candidate should has membership card to choose and read the book outside from library. Safety is the first priority of the custodian of the book. In case of any type of damage member has to pay for the damage. Libraries serves in educational activities, therefore it is like back bone for those students who do not bear the expenditures of education.

There is conflict about what measures ought to be look at to decide adequacy, who ought to build up viability models and how rules ought to be utilized in assessing viability. It is simpler to assess if the standards are equipped for quantitative estimation. This straightforwardness with which quantitative information can be gathered may be said to have deflected curators from attempting to find the adequacy of their frameworks in wording identifying with clients, which might be more significant. The viability of library assets and administrations can be estimated differently. Various analysts have introduced various structures of assessment standards. (Library Effectiveness Library \& Information Science Network, 2018).

Ene (1978) specified that effectiveness of libraries should be examined from the objectives recognized by the library.

As cited by (Shaqiri, 2015) library in educational activities is an informal technique to increase educational, cognitive, psychological and physical capabilities of an individual. Library providing his services to all and its access is open every time to every member of the society Some of the reasons why a library is important for students are it are a treasure-trove of knowledge, it is divided into a number of sections or departments on the basis of certain subjects to learn, and it provides the students a very healthy environment. Another important fact about the multiple role of libraries for students is that it helps students to keep very good concentration on their studies Stephen, Maeve \& Philips (2007).

The effectiveness of libraries are, conventionally measured through quantifiable grounds but recently this is not the only method for measuring the effectiveness of libraries with an increase in responsibility and awareness novel ways and methods are adopted to measure the effectiveness of resources and services that a library offers. Such methods measure the level of satisfaction regarding the user's needs and expectations (Abdullah \& Bilal, 2015).

A well cited website described the characteristics of the $21^{\text {st }}$ century library that include less physical materials, learning environment that is flexibility, remoteless connectivity, easily accessible resources, services that support academic integration and availability of food and drink facilities (Account \& partnership, et al., 2021)

\subsection{STATEMENT OF THE PROBLEM}

Educational activities are thousand to engage students in which one greatest and important is Information technology which helps in the promotion of library facilities. Students use library as a part of educational activities as rules and policy mention by Higher Education Commission at higher level therefore, the present study aimed to explore the multiple roles of library in student's educational activities at University level.

\subsection{OBJEETIVES OF THE STUDY}

1. To explore the multiple roles of library in student's educational activities at University level.

\subsection{RESEARCH QUESTIONS}

1. Does library play multiple roles in the promotion of educational activities at university 
Vol. II, Issue 3, Oct - December 2021

ISSN No: (ONLINE): 2710-043

www.irjei.com
International Research Journal of Education and Innovation

ISSN No: ISSN (PRINT): 2710-0448

DOI: https://doi.org/10.53575/irjei.v2.03(21)5.53-66

An Exploration of The Multiple Role of Library in The Educational Activities ...

level?

2. Does University libraries effective in cognitive development, academic development and personality development?

\section{SIGNIFICANCE OF THE STUDY}

The study was significant for teachers and students in the present era to utilize digital and scientific facilities to libraries at higher level. University teachers and administration will took serious actions to provide all emerging facilities to libraries. So, that students and teachers interact through library in educational activities rendering to their prerequisites.

\section{LITERATURE REVIEW}

A powerful library is characterized as a library that, given the setting where it works, performs well in correlation with different libraries (Glorieux, Kuppens, \& Vandebroeck 2007). A successful library is characterized here as a library that, given the setting wherein it works, performs well in correlation with different libraries. Accomplishing viability in library administrations is considered as the fundamental obligation of the library the board.

Majid, Anwar \& Eisenschitz (2010) concluded that the effectiveness of libraries was associated with the adequate collection of resources available.

As McCarthy (1995) studied the Students' Perceived Effectiveness Using the University Library and collected data from the number of eighteen hundred university students. The researcher find out that the university undergraduates were pleased from the facilities provided by the university collection of books and learning materials as the students were adequate used CD-ROM data base and other inline services. Researcher was also found that university students were more pleased and confidence than the undergraduate. Most of the libraries are confused of whether their students have access to the resources physically and mentally is adequate or not. The libraries must understand the current status regarding the skills, information and satisfaction of students while using the resources of library.

A library is considered as a significant and vital segment of any top notch research organization. Designing examination is no exemption for this. The present specialized libraries are relied upon to multi-disciplinary, multi-mode, multi-media as the specialized instruction requests it to assume the supporting part. Webb, Miller \& Knapp (2007) stated that libraries need to ceaselessly stay in contact with the examination local area to understand what they truly need from the library. The contact may as application support and simulated presence in online conditions or individual perception. Libraries need to move away from an uninvolved, receptive part to a more dynamic one to expect just as react to requests from scientists. By staying in contact, libraries may see all varieties in learning and in research practice that happen in the examination local area. This assists administrators with guaranteeing that they are giving a scope of assets to meet these various necessities and furthermore to comprehend that individuals will decide to utilize various assets in an unexpected way. Libraries can't give a one size fits all libraries and anticipate that it should be fruitful; compelling administrations lay on information and compassion (Kumar 2017).

Meanings of library adequacy have gone from specialized effectiveness measures to obscure explanations of goodness, however most have zeroed in on objective accomplishment, proficiency, client fulfillment, staff the board, and capacity of the association to endure. In 
Vol. II, Issue 3, Oct - December 2021

ISSN No: (ONLINE): 2710-043

www.irjei.com
International Research Journal of Education and Innovation

ISSN No: ISSN (PRINT): 2710-0448

DOI: https://doi.org/10.53575/irjei.v2.03(21)5.53-66

An Exploration of The Multiple Role of Library in The Educational Activities ...

view of a perusing of expert endeavors to figure this out (Kao \& Lin 2004; McDonald \& Micikas, 1994) doubtlessly the terms quality and adequacy are being utilized to mean exactly the same thing: accomplishing a nature of administration that fulfills to a serious level the data and examination needs of personnel, understudies, and different clients; that contributes verifiably to the achievement of the establishment's instructive and formative objectives; and that achieves this in an operationally viable way. At the point when one attempt to make sure about the ramifications of this definition, barricades rapidly seem powerful by what standards, meeting what level of necessities, at what cost, for what reason!

Khan (2014) carried out a study in the University of Allahabad to measure the effectiveness of the collection of materials, and the educational facilities by the central library of the said university. The research were also analyzed users' responses regarding collection of materials, organization of collected materials, conveniences provided by the library along with its provided services. Data was collected from teachers, students and research scholars of the Allahabad University through a survey. Findings of the study show that the library does not have a best collection of books etc. but also the respondents averagely rated function, organization and facilities available in the library. Besides this the library staff was behavior with the clienteles were found unsatisfied.

Ayob (2011) highlighted the importance of adequate collection of the library used by researchers, as the adequate resources collection that support the activities of researcher is the criteria for evaluating university's efficiency. Furthermore, Kao \& Lin 2004 specified the resources or materials used by researchers that mostly used resources included the collection of books, abstracts and journals.

Adegun, Oyewumi, Oladapo, \& Sobalaje (2015) were of the opinion that through analysis of the services provided by library, effectiveness of the specific library can be guessed. A University library full of valuable resources acts as the guide for researchers and provide basis for further discovery of novel areas in the field of research.

Normally the effectiveness of the libraries is measured through the resource model of the system by input count, the input is not able to highlight and link the output that why it cannot measure the effectiveness of libraries (Ayob, 2011).

Khan \& Zaidi (2011) carried out a study to know the opinions of the users of library regarding the resources collection, satisfaction of the users regarding the resources of collection in library, the organization of the collected resources and services offered by the library at university level. Data collection was done through a well-organized questionnaire. Target for data collection were the teaching faculty, students and research graduates from the University of Maulana Azad, India. The results of the survey revealed that the collection of resources of the University library was adequately enough for the users of the said library. The results also showed that the users were satisfied with the overall organization and infrastructure of the university library and considered it effective.

Pan, Vinent and Bruehl (2014) studied library Value in the Classroom: Assessing Student Learning Outcomes from Instruction and Collections. They conducted the study in University of Colorado (CU) Denver, in the course of subject Chemistry and get positive results. They concluded that if we want to ensure that those skills are applied within other courses, that there is meaningful transfer to other learning environments, and that ultimately the quality of the student's work is improved, the assessment methodology moves beyond library 
Vol. II, Issue 3, Oct - December 2021

ISSN No: (ONLINE): 2710-043

www.irjei.com
International Research Journal of Education and Innovation

ISSN No: ISSN (PRINT): 2710-0448

DOI: https://doi.org/10.53575/irjei.v2.03(21)5.53-66

An Exploration of The Multiple Role of Library in The Educational Activities ...

control into collaborative efforts with teaching faculty (Khan \& Muhammad, 2012).

Onuoha \& Uloma (2013) carried out a descriptive research study in order to explore the usage, effectiveness along with user's satisfaction from the services of library at Babcock University in Nigeria. Population of the study comprised a total of 5,847 students of the said University at undergraduate level. A number of two hundred students were selected as sample through purposive sampling technique. Survey was used as instrument for data collection from the selected sample. Collected data was analyzed through frequency along with percentage calculation. Results of the data analysis showed that highly utilized services were reference services and photocopying services, as well as they were regarded the most effective services. However, most of the undergraduate students were fairly satisfied with the services offered by the University library.

Similarly, Ezeala (2009) conducted a research to find out the effectiveness of the resources of libraries of ARI (Agriculture Research Institute) in Nigeria. Research officers including doctors of vets, scientists of medical laboratory and animal health, along with biochemist and agricultural scientists, from fourteen research institutes of agriculture were the population of the study. Data for the study was collected through a survey. Findings of the study show that the libraries associated with agriculture institutes for research were ineffective from the perspective of the users. The study also found a lack of support for the mandate of research institutes.

Abdullah \& Bilal (2015) conducted a survey to examine the services and resources of information of libraries. The target of the study was four universities of Lebanon. Questionnaire was used an instrument for data collection. Data collected from 865 questionnaires show that participants were not satisfied with the provided computers, services and the resources by libraries. The students of only one of four universities were satisfied from the materials and services availed by library. The services that very found excellent were hygienic and safe environment of the library. The researchers emphasized on the access of students to essential resources which are necessary for educational activities. Pan, Wiersma, Williams \& Fong (2013) were of the opinion that through analysis of the services provided by library, effectiveness of the specific library can be guessed. The researchers concluded that a library full of valuable resources acts as the guide for researchers and provide basis for further discovery of novel areas in the field of research.

Kinman (2009) stated in his research study E-Metrics and Library Assessment in Action that measuring the effectiveness of libraries by stating that the effectiveness of a library can be seen through satisfaction of users' needs. It means if a library fulfils and satisfies the needs of its users, one can say that library is effective. The researcher also believes as above with a little addition that effectiveness can be measured by users' satisfaction of needs along with achievement of the library's present objectives.

Adegun, Oyewumi, Oladapo \& Sobalaje (2015) carried out a study to assess the effectiveness of the services and collection of the library in the context of an African University. Data was collected from five hundred students randomly. Frequency distribution and percentage were used for the analysis of collected data. According to the collected results seventy three percent $(73 \%)$ of the total students were satisfied from the services of the university library. In the context of resources or collection of the library fifty three percent (53\%) of students were satisfied. According to the study along with some inadequacy of resources, the available 
Vol. II, Issue 3, Oct - December 2021

ISSN No: (ONLINE): 2710-043

www.irjei.com
International Research Journal of Education and Innovation

ISSN No: ISSN (PRINT): 2710-0448

DOI: $\underline{\text { https://doi.org/10.53575/irjei.v2.03(21)5.53-66 }}$

An Exploration of The Multiple Role of Library in The Educational Activities ...

resources were user-friendly and reachable without any difficulty.

Ayob \& Sendut (2011) conducted a survey study to examine the services provided by academic libraries in Malaysian university for researchers. The determination of conducting the survey the researcher used a self-developed questionnaire for the collection of data. Four areas for examination were selected the resources and services are provided by the universities, the interaction between the stakeholders and ease of access to library materials etc. researchers point of view regarding the effectiveness and ineffectiveness was extracted from the results of the survey. The study also highlighted inter-relationship between demographic features and the researcher's activities of the library. The results show that the materials available were fairly adequate for the use of researchers' needs. Moreover, less than fifty percent of the respondents agreed to the statement of effectiveness of the services provided by library. The findings of the study also show a great accessibility of online resources by researchers.

Ivanitskaya, DuFord, Craig \& Casey (2008) studied the impact of feedback in relation to pretest on the library instruction's effectiveness. The study collected data from the students who were engaged in their Master's studies. Data collection was done through Research Readiness Self-Assessment (RRSA), separately from each degree's group. Group A was provided with feedback after the pre-test and before the post-test, while group B was only provided with post-test. The findings showed that as group A completed both Pre-test and post-test achieved higher score than group B. the study also suggests that users of libraries should give feedback on the pre-test for the effectiveness of library instructions.

\section{METHODOLOGY}

NATURE OF THE STUDY

The study is descriptive in nature. A questionnaire was developed by the researcher and administered by her. The data was collected analyzed and tabulated accordingly

\section{POPULATION OF THE STUDY}

For the purpose to explore the multiple role of library in educational activities, therefore all undergraduates of selected departments of social sciences discipline of Abdul Wali Khan University Mradan was taken as a population of the study.

\section{SAMPLE OF THE STUDY}

It was difficult to collect data from all undergraduates so; the researcher randomly selected number of hundred students from the following departments of social sciences chunk. Number of twenty five undergraduates was taken from each department.

\begin{tabular}{llll}
\hline S/No & Name of Department & Number of Students (Male + Female) \\
\hline 1 & Education & 10 Female & 15 Male \\
2 & Sociology & 15 & 10 \\
3 & Tourism \& Hospitality & 8 & 17
\end{tabular}


Vol. II, Issue 3, Oct - December 2021

ISSN No: (ONLINE): 2710-043

www.irjei.com
International Research Journal of Education and Innovation ISSN No: ISSN (PRINT): 2710-0448

DOI: https://doi.org/10.53575/irjei.v2.03(21)5.53-66

An Exploration of The Multiple Role of Library in The Educational Activities ...

\begin{tabular}{llll}
\hline \hline 4 & Islamiyat & 16 & 09 \\
\hline Total & 49 & 51 \\
\hline
\end{tabular}

\section{DATA COLLECTION}

A Questionnaire was developed in which fourteen items were related to explore the multiple role of library in educational activities at university level and distributed among the participants to assemble data.

\section{TUBULATION OF DATA}

The collected data was tabulated accordingly and stated in percentage \%, Mean and STD/ standard deviation. Collected data was tabulated the results were presented accordingly. The respondents were questioned to response in always, often and to some degree.

\section{Data Analysis}

Categorization of Mean

.50-1.19 Below Average

1.20-1.89 Average

1.90-2.59 Above Average

Table 1: Students Visit to Library

\begin{tabular}{|c|c|c|c|c|c|c|}
\hline Categories & Frequency & Percent & Valid & Cumulative & Mean & $\begin{array}{l}\text { Std/ } \\
\text { Deviation }\end{array}$ \\
\hline Always & 43 & 43 & 43 & 43 & & \\
\hline Often & 33 & 33 & 33 & 76 & 1.81 & .800 \\
\hline To some degree & 24 & 24 & 24 & 100.0 & & \\
\hline Total & 100.0 & 100.0 & 100.0 & & & \\
\hline \multicolumn{7}{|c|}{$\begin{array}{l}\text { Table } 1 \text { shows } 43 \% \text { university students responded that they visit library regularly, } 33 \% \\
\text { students often visit to library while } 24 \% \text { respondents responded that they visit library to } \\
\text { some degree. Furthermore mean score } 1.81 \text { indicated averages according to the given } \\
\text { categorization while Std /deviation is } .800 \text {. } \\
\text { Table } 2 \text { Students go to library to Read Newspaper }\end{array}$} \\
\hline Categories & Frequency & Percent & Valid & $\begin{array}{l}\text { Cumulative } \\
\text { percent }\end{array}$ & Mean & $\begin{array}{l}\text { Std/ } \\
\text { Deviation }\end{array}$ \\
\hline Always & 35 & 35 & 35 & 35 & & \\
\hline Often & 25 & 25 & 25 & 60 & 2.05 & .869 \\
\hline To some degree & 40 & 40 & 40 & 100.0 & & \\
\hline Total & 100.0 & 100.0 & 100.0 & & & \\
\hline
\end{tabular}

Table 2 shows that $35 \%$ university students responded that they always go to library to read newspapers while 25\% students often and $40 \%$ students agree with the statement to some degree. Furthermore mean score 2.05 indicated as an above average according to the given 
Vol. II, Issue 3, Oct - December 2021

ISSN No: (ONLINE): 2710-043

www.irjei.com
International Research Journal of Education and Innovation ISSN No: ISSN (PRINT): 2710-0448

DOI: https://doi.org/10.53575/irjei.v2.03(21)5.53-66

An Exploration of The Multiple Role of Library in The Educational Activities ...

categorization and the Std /deviation is .869 .

Table 3 Place of Awareness about Current Issues

\begin{tabular}{ccccccc}
\hline Categories & Frequency & Percent & Valid & Cumulative & Mean $\begin{array}{c}\text { Std/ } \\
\text { Deviation }\end{array}$ \\
\hline Always & 51 & 51 & 51 & 51 & 69 & 1.80 \\
Often & 18 & 18 & 18 & 100.0 & & .888 \\
To some degree & 31 & 31 & 31 & & \\
Total & 100.0 & 100.0 & 100.0 & & & \\
\hline
\end{tabular}

Table 3 that $51 \%$ participants responded positively that university library is a place of mindfulness about currant issues while 31\% answered to some degree. Mean score 1.80 indicated as an average according to the given categorization and the Std /deviation is .888.

Table 4 Helpful in developing the Knowledge

\begin{tabular}{ccccccc}
\hline Categories & Frequency & percent & Valid & $\begin{array}{c}\text { Cumulative } \\
\text { percent }\end{array}$ & Mean & $\begin{array}{c}\text { Std/ } \\
\text { Deviation }\end{array}$ \\
\hline Always & 68 & 68 & 68 & 68 & & \\
Often & 24 & 24 & 24 & 92 & 1.40 & .636 \\
To some degree & 8 & 8 & 8 & 100.0 & & \\
Total & 100.0 & 100.0 & 100.0 & & & \\
\hline
\end{tabular}

Table 4 indicates that $68 \%$ university participants positively in the favor of the statement while $24 \%$ responded that library is a source of developing the academic knowledge and only $8 \%$ to some degree. Mean score 1.40 indicated as an average according to the given categorization and the Std /deviation is .636.

Table 5 Helpful in Personality Development

\begin{tabular}{ccccccc}
\hline Categories & Frequency & Percent & $\begin{array}{c}\text { Valid } \\
\text { Percent }\end{array}$ & $\begin{array}{c}\text { Cumulative } \\
\text { Percent }\end{array}$ & Mean & $\begin{array}{c}\text { Std/ } \\
\text { Deviation }\end{array}$ \\
\hline Always & 46 & 46 & 46 & 46 & & \\
Often & 24 & 24 & 24 & 80 & 1.74 & .774 \\
To some degree & 20 & 20 & 20 & 100.0 & & \\
Total & 100.0 & 100.0 & 100.0 & & & \\
\hline
\end{tabular}

Table 5 indicates that $46 \%$ university participants positively in the favor of the statement although $32 \%$ responded that library as an agent towards personality development while $20 \%$ were agree to some degree. Mean score 1.74 indicated as an average according to the given categorization and the Std /deviation is .774.

Table 6 Place of Preparation during Formative and Summative Assessments 
Vol. II, Issue 3, Oct - December 2021

ISSN No: (ONLINE): 2710-043

www.irjei.com
International Research Journal of Education and Innovation ISSN No: ISSN (PRINT): 2710-0448

DOI: https://doi.org/10.53575/irjei.v2.03(21)5.53-66

An Exploration of The Multiple Role of Library in The Educational Activities ...

\begin{tabular}{ccccccc}
\hline \hline Categories & Frequency & Percent & Valid Percent & $\begin{array}{c}\text { Cumulative } \\
\text { Percent }\end{array}$ & Mean & $\begin{array}{c}\text { Std/ } \\
\text { Deviation }\end{array}$ \\
\hline Always & 47 & 47 & 47 & 47 & & \\
Often & 29 & 29 & 29 & 76 & 1.77 & .815 \\
To some degree & 24 & 24 & 24 & 100.0 & & \\
Total & 100.0 & 100.0 & 100.0 & & & \\
\hline
\end{tabular}

Table 6 indicates that $47 \%$ university participants positively in the favor of the statement although 29\% responded that library is helpful in personality development while $24 \%$ were agree to some degree. Mean score 1.77 indicated as an average according to the given categorization and the Std /deviation is .815

\section{Table 7 Allowed easy Access to Printed Material}

\begin{tabular}{ccccccc}
\hline Categories & $\begin{array}{c}\text { Frequenc } \\
\mathbf{y}\end{array}$ & Percent & $\begin{array}{c}\text { Valid } \\
\text { Percent }\end{array}$ & $\begin{array}{c}\text { Cumulative } \\
\text { Percent }\end{array}$ & Mean & $\begin{array}{c}\text { Std/ } \\
\text { Deviation }\end{array}$ \\
\hline Always & 72 & 72 & 72 & 72.7 & & \\
Often & 17 & 17 & 17 & 89.9 & 1.37 & .664 \\
To some degree & 10 & 10 & 10 & 100.0 & & \\
Total & 100.0 & 100.0 & 100.0 & & & \\
\hline
\end{tabular}

Table 7 indicates that $72 \%$ university participants positively in the favor of the statement although $17 \%$ responded that due to library we make easily access to printed material while only $10 \%$ were agree to some degree. Mean score 1.37 indicated as an average according to the given categorization and the Std /deviation is .664.

\section{Table 8 Opt Library Rather than Internet}

\begin{tabular}{|c|c|c|c|c|c|c|}
\hline Categories & Frequency & Percent & $\begin{array}{c}\text { Valid } \\
\text { Percent }\end{array}$ & $\begin{array}{c}\text { Cumulative } \\
\text { Percent }\end{array}$ & Mean & Std/Deviation \\
\hline Always & 46 & 46 & 46 & 46.5 & & \\
\hline Often & 26 & 26 & 26 & 72.5 & 1.81 & .841 \\
\hline $\begin{array}{l}\text { To some } \\
\text { extant }\end{array}$ & 27 & 27 & 27 & 100.0 & & \\
\hline Total & 100.0 & 100.0 & 100.0 & & & \\
\hline
\end{tabular}


Vol. II, Issue 3, Oct - December 2021

ISSN No: (ONLINE): 2710-043

www.irjei.com
International Research Journal of Education and Innovation ISSN No: ISSN (PRINT): 2710-0448

DOI: https://doi.org/10.53575/irjei.v2.03(21)5.53-66

An Exploration of The Multiple Role of Library in The Educational Activities ...

replied often and 33\% to some degree that students opt library rather than interne therefore mean score 1.81 were found in the category of average and the Std $\backslash$ deviation is .841.

Table 9 Treasure of Books

\begin{tabular}{ccccccc}
\hline Categories & $\begin{array}{c}\text { Frequenc } \\
\text { y }\end{array}$ & $\begin{array}{c}\text { Percen } \\
\mathbf{t}\end{array}$ & $\begin{array}{c}\text { Valid } \\
\text { Percent }\end{array}$ & $\begin{array}{c}\text { Cumulative } \\
\text { Percent }\end{array}$ & Mean & $\begin{array}{c}\text { Std/ } \\
\text { Deviation }\end{array}$ \\
\hline Always & 43 & 43 & 43 & 43 & & \\
Often & 29 & 29 & 29 & 72 & 1.85 & .833 \\
To some degree & 28 & 28 & 28 & 100.0 & & \\
Total & 100.0 & 100.0 & 100.0 & & & \\
\hline
\end{tabular}

Table 9 intended that $43 \%$ university students responded that library is treasure of books while, $29 \%$ were repeatedly agree and $28 \%$ to some degree. Therefore mean score is 1.85 which is above average according to the selected categorization while standard deviation is .833.

Table 10 Appropriate Information is Available

\begin{tabular}{ccccccc} 
Categories & Frequency & Percent & $\begin{array}{c}\text { Valid } \\
\text { Percent }\end{array}$ & $\begin{array}{c}\text { Cumulative } \\
\text { Percent }\end{array}$ & Mean & $\begin{array}{c}\text { Std/ } \\
\text { Deviation }\end{array}$ \\
\hline Always & 32 & 32 & 32 & 32.3 & & \\
Often & 34 & 34 & 34 & 66.7 & 2.01 & .814 \\
To some degree & 33 & 33 & 33 & 100.0 & & \\
Total & 100.0 & 100.0 & 100.0 & & & \\
\hline
\end{tabular}

Table 10 shows that $32 \%$ university respondents agreed with the given statement while, $34 \%$ replied often and $33 \%$ to some degree therefore mean score 2.01 were found in the category of above average and the $S t d \backslash$ deviation is .814 .

Table 11 Environment Snatch My Mind for Reading

\begin{tabular}{ccccccc}
\hline Categories & $\begin{array}{c}\text { Frequenc } \\
\mathbf{y}\end{array}$ & Percent & $\begin{array}{c}\text { Valid } \\
\text { Percent }\end{array}$ & $\begin{array}{c}\text { Cumulative } \\
\text { Percent }\end{array}$ & Mean & $\begin{array}{c}\text { Std/ } \\
\text { Deviation }\end{array}$ \\
\hline Always & 44 & 44 & 44.9 & 44.9 & & \\
Often & 38 & 38 & 38.8 & 83 & 1.71 & .732 \\
To some degree & 16 & 16 & 16.3 & 100.0 & & \\
Total & 98.0 & 98.0 & 100.0 & & & \\
\hline
\end{tabular}

Table 11 shows that $44 \%$ respondents were in the favor that the learning environment of library snatches their mind for reading while $38 \%$ responded often and $16 \%$ were responded to some degree. Consequently mean score is 1.71 which is an average according to the categorization and Std $\backslash$ deviation is .732.

Table 12 Upsurge Terminologies 
Vol. II, Issue 3, Oct - December 2021

ISSN No: (ONLINE): 2710-043

www.irjei.com
International Research Journal of Education and Innovation ISSN No: ISSN (PRINT): 2710-0448

DOI: https://doi.org/10.53575/irjei.v2.03(21)5.53-66

An Exploration of The Multiple Role of Library in The Educational Activities ...

\begin{tabular}{ccccccc}
\hline \hline Categories & Frequency & Percent & $\begin{array}{c}\text { Valid } \\
\text { Percent }\end{array}$ & $\begin{array}{c}\text { Cumulati } \\
\text { ve } \\
\text { Percent }\end{array}$ & Mean & $\begin{array}{c}\text { Std/ } \\
\text { Deviation }\end{array}$ \\
\hline Always & 56 & 56 & 56 & 56 & & \\
Often & 30 & 30 & 30 & 86 & 1.58 & .727 \\
To some degree & 14 & 14 & 14 & 100.0 & & \\
Total & 100.0 & 100.0 & 100.0 & & & \\
\hline
\end{tabular}

Table 12 shows that $56 \%$ respondents were in the favor that library upsurge terminologies while $30 \%$ responded often and $14 \%$ were responded to some degree. Consequently mean score is 1.58 which is an average according to the categorization and Std \deviation is .727.

Table 13 Practice CPU in library

\begin{tabular}{ccccccc}
\hline Categories & Frequency & Percent & $\begin{array}{c}\text { Valid } \\
\text { Percent }\end{array}$ & $\begin{array}{c}\text { Cumulativ } \\
\text { e Percent }\end{array}$ & Mean & $\begin{array}{c}\text { Std/ } \\
\text { Deviation }\end{array}$ \\
\hline Always & 44 & 44 & 44 & 44 & & \\
Often & 36 & 36 & 36 & 80 & 1.76 & .767 \\
To some degree & 20 & 20 & 20 & 100.0 & & \\
Total & 100 & 100 & 100.0 & & & \\
\hline
\end{tabular}

Table 13 shows that $44 \%$ university students responded that they always practice CPU at library easily while $36 \%$ often uses and $20 \%$ to some degree consequently mean score is 1.76 which is average according to categorization and Std $\backslash$ deviation is .767.

Table 14 Helpful in Educational Development

\begin{tabular}{ccccccc}
\hline Categories & Frequency & Percent & $\begin{array}{c}\text { Valid } \\
\text { Percent }\end{array}$ & $\begin{array}{c}\text { Cumulative } \\
\text { Percent }\end{array}$ & Mean & $\begin{array}{c}\text { Std/ } \\
\text { Deviation }\end{array}$ \\
\hline Always & 63 & 63 & 63 & 63 & & \\
Often & 24 & 24 & 24 & 87 & 1.50 & .718 \\
To some degree & 13 & 13 & 13 & 100.0 & & \\
Total & 98.0 & 98.0 & 100.0 & & & \\
\hline
\end{tabular}

Table 14 intended that $63 \%$ university participants give positive response in the favor of the statement although $24 \%$ responded often while $13 \%$ were agreed to some degree. Consequently the mean score 1.50 indicated as an average according to the given categorization and the Std /deviation is .718. 
Vol. II, Issue 3, Oct - December 2021

ISSN No: (ONLINE): 2710-043

www.irjei.com
International Research Journal of Education and Innovation

ISSN No: ISSN (PRINT): 2710-0448

DOI: https://doi.org/10.53575/irjei.v2.03(21)5.53-66

An Exploration of The Multiple Role of Library in The Educational Activities ...

\section{FINDINGS \& DISCUSSION}

The results indicates that $43 \%$ university students have library cards and the mean score is 1.81 as an average showed that students happily visit library for educational activities. The results exposed that $35 \%$ university students always go to library to read newspaper and get information to update with current issues. The 2.05 mean score is above average in the categorization clearly specifies that students take interest in reading newspapers. Data results showed that $51 \%$ university students responded that library is a place of awareness about current issues related to educational activities which mean that students go to library for educational awareness consequently the mean score is 1.80 shows average response.

The study revealed that a $68 \%$ university student distinguishes the importance of library they positively responded that library is an agent to boosting up the knowledge and academic skills of the students. The results intended that $45 \%$ of university graduates responded positively mean score of 1.74 indicates that library is accommodating the personality development. The results showed that $47 \%$ university students always use library for the purpose of formative and summative assessments. Consequently the mean score 1.77 support the statement. The results revealed that $72 \%$ university students always uses library as a free access to printed material. Therefore mean score of the data 1.37 supports the statement.

Results intended that $46 \%$ university students choose and enjoy reading the books rather than the use of internet or expensive internet packages. The study results indicated that $43 \%$ students sought out the relevant books according to their academic needs. The 1.85 mean score also support the results which means that high number of students originate library as a treasure of books. The university students responded that appropriate information is available at library at any time free of cost. The mean score 2.01 is above average exposed the level of the students satisfaction regarding the accessibility of material. The results revealed that $44 \%$ university like the environment of library to snatch their mind for reading therefore mean 1.71 shows that university library providing help to develop reading skills.

The results of the study revealed that 56\% students are satisfied that they increase their terminology which means library play positive role to build up educational activities.

Results indicates that $44 \%$ students always use CPU in library, the average mean score of the data is 1.76 shows that students uses computer in library regularly as the representatives of the educational activities. The results of the study stated that $63 \%$ university students positively responded regarding vigorous role of the library in promotion of educational activities therefore the result towards positive attitude towards prevalent of educational activities.

\section{CONCLUSIONS}

It was concluded from the results that library plays a fundamental role in the promotion of educational activities at university level. It provides maximum information regarding current issues, awareness of digital and information resources. Just like a treasurer library have also numerous zone to find and enrich the data of education of an individual. The study also find out that despite of all the developmental areas of educational and cognitive development library can develop the personality of an individual i.e he/she can easily understand his/her position in the society. It was concluded that in the present era of Technology the university 
Vol. II, Issue 3, Oct - December 2021

ISSN No: (ONLINE): 2710-043

www.irjei.com
International Research Journal of Education and Innovation

ISSN No: ISSN (PRINT): 2710-0448

DOI: https://doi.org/10.53575/irjei.v2.03(21)5.53-66

An Exploration of The Multiple Role of Library in The Educational Activities ...

students prefer and enjoy reading books rather than the internet or expensive internet packages. From the above research it can be extracted that an effective library must ensure the best collection of resources including, books, journals and other academic, leisure's and informative materials. An effective library must have dignified, helpful and courteous staff, along with ease of accessibility physically as well as online. The library services must be timely delivered and training for the use of library enhances the effectiveness of library at university level.

\section{RECOMMENDATIONS}

1) Higher Education Commission in Pakistan should arranged library catalogue training for all University teachers.

2) Incentives should be given to those students who visit regularly to library

3) Special online courses should be introduced to implement library and books in educational activities

4) Grants for inter departmental libraries should be provided easily.

5) Seminar and workshops for students should be arranged by the administration of library in the Universities of Pakistan.

\section{REFERENCES}

1. Abdallah, F., \& Bilal, D. (2015). Exploring the Effectiveness of Library Services and Resources in Academic Libraries in Lebanon from Users' Perspectives.

2. Account, C., Partnership, L., Us, C., Partnership, L., Account, C., \& Partnership, L. et al. (2021). Characteristics of the 21st-century library | EAB. Retrieved 10 May 2021, from https://eab.com/insights/expert-insight/facilities/characteristics-of-the-21st-century-library.

3. Adegun, A., Oyewumi, O. O., Oladapo, Y. O., \& Sobalaje, A. J. (2015). Effectiveness of library service and resources in an African university. In Information and Knowledge Management (Vol. 5, No. 3, pp. 54-59).

4. Akinpelu, J. A. (1994). Education for Special Groups" In: 0.0. Akinkugbe, ed. Nigeria and Education: The Challenges Ahead, Ibadan: Spectrum Books Ltd; Pg. 158-190.

5. Ayob, A. (2011). An Assessment of the Effectiveness of Library Resources and Services in Supporting Researchers' Information Needs. Seminar Kebangsaan Perpustakaan Akademik 2011.

6. Ayob, A., \& Sendut, P. H. (2013). An assessment of the effectiveness of library resources and services in supporting researchers' information needs (Doctoral dissertation, Jabatan Sains Maklumat, Fakulti Sains Komputer dan Teknologi Maklumat, Universiti Malaya).

7. Ene, N. (1978). Analysis of the clientele of the public libraries in Benin-City and the effectiveness the libraries in meeting their needs. Unpublished doctoral dissertation, University of Ibadan.

8. Ezeala, L. O. (2009). Effectiveness of library Resources in the libraries of Agricultural Research institutes in Nigeria. Library Philosophy and Practice.

9. Glorieux, I., Kuppens, T., \& Vandebroeck, D. (2007). Mind the gap: Societal limits to Public Library Effectiveness. Library \& information science research, 29(2), 188-208.

10. Ivanitskaya, L., DuFord, S., Craig, M., \& Casey, A. M. (2008). How does a pre-assessment of offcampus students' information literacy affect the effectiveness of library instruction?. Journal of Library Administration, 48(3-4), 509-525.

11. Kao, C., Lin, Y. C. (2004). Evaluation of the University Libraries in Taiwan: total measures verses ratio measures. The Journal of the Operational Research Society Pp. 1256-1265. Published By: Palgrave Macmillan Journals. https://www.jstor.org/stable/4101845.

12. Kinman, V. (2009). E-Metrics and Library Assessment in Action. Journal of Electronic Resources 
Vol. II, Issue 3, Oct - December 2021

ISSN No: (ONLINE): 2710-043

www.irjei.com
International Research Journal of Education and Innovation

ISSN No: ISSN (PRINT): 2710-0448

DOI: https://doi.org/10.53575/irjei.v2.03(21)5.53-66

An Exploration of The Multiple Role of Library in The Educational Activities ...

Librarianship, 21:1, 15-36, DOI: 10.1080/19411260902858318.

13. Khan, A. M. (2014). Measuring Effectiveness and Efficiency of an Academic Library's Collection and Services of the Central Library, Allahabad University: Users' Point of View. International Information \& Library Review, 46(1-2), 31-40.

14. Khan, A. M., \& Zaidi, S. M. (2011). Determinants of library's effectiveness and efficiency: A study of collection development, organization and services of Maulana Azad Library, AMU (India). Library Collections, Acquisitions, and Technical Services, 35(4), 95-105.

15. Kumar, P. A. (2017). Impact of Information Technology on the Collection Development in University Libraries of Assam: A Study. Retrieved from: https://www.lisbdnetwork.com/informationtechnology-and-library.

16. Library Effectiveness - Library \& Information Science Network. (2018). Retrieved 11 May 2021, from https://www.lisbdnetwork.com/libraryeffectiveness.

17. Majid, S., Anwar, M. A., \& Eisenschitz, T. S. (2001). User perceptions of library effectiveness in Malaysian agricultural libraries. Library Review.

18. McCarthy, A. C. (1995). Students' Perceived Effectiveness Using the University Library. College and Research Library. Volume 56. University of Rhode Island Graduate School of Library and Information Studies, Rodman Hall, Kingston, Rhode Island 02881-0815.

19. McDonald, J. A., \& Micikas, L. B. (1994). Academic Libraries: The Dimensions of Their Effectiveness. New Directions in Information Management, Number 32. Greenwood Press, 88 Post Road West, Westport, CT 06881.

20. Onohwakpor, J. E. (2005). The Role of Library Services in Adult Literacy Education". of Library Philosophy and Practice (e-Journal). Vol. 7, No. 2 (Spring 2005) (libr.unl.edu:2000/LPP/lppv7n2.htm) ISSN 1522-0222.

21. Onuoha, U. D., Omokoje, A., \& Bamidele, I. A. (2013). Assessing service effectiveness and satisfaction with library services at Babcock University, Nigeria. In Information and Knowledge Management (Vol. 3, No. 9, pp. 84-90).

22. Pan, D., Vinent, F. I.. \& Bruehl , M. (2014). Library Value in the Classroom: Assessing Student Learning Outcomes from Instruction and Collections. The Journal of Academic Librarianship. http://dx.doi.org/10.1016/j.acalib.2014.04.011.

23. Pan, D., Wiersma, G., Williams, L., \& Fong, Y. (2013). More Than a Number: Unexpected Benefits of ROI Analysis for Collection Development. The Journal of Academic Librarianship, 39(6), 566-572.

24. Shaqiri, B. A. (2015). Management Information System and Competitive Advantage. Mediterranean Journal of Social Sciences MCSER Publishing, Rome-Italy ISSN 2039-2117 (online) ISSN 2039-9340 (print) Vol 6 No 1 P204-208. Doi:10.5901/mjss.2015.v6n1p204.

25. Stephen, H., Maeve. C., Phillips. A. (2007). Management Information Systems for the Information Age. 2007, McGraw-Hill Irwin. p.24.

26. Webb, E. J., Miller, R. P., \& Knapp, A. (2008). Providing effective library services for research. Journal of the Medical Library Association JMLA 96(3). DOI: 10.3163/1536-5050.96.3.020 Source PubMed Central Pp. 220 